\title{
Marx's Philosophy of Revolution in Permanence: Its Significance for Our Time
}

\author{
Franklin Dmitryev* and Eugene Gogol** \\ *franklin.dmitryev@gmail.com \\ **egogol@hotmail.com
}

\begin{abstract}
How can Marx's ideas help us with the problem of how to make new revolutionary beginnings in a time when the counterrevolution is ascendant, without losing sight of the need to prepare for the equally crucial question of what happens after the revolution? Capitalism has taken various forms as it developed, with the latest shaped by its endemic crisis since the mid-1970s generated by its falling rate of profit. Throughout these stages, the humanism and dialectic of Capital remain prime determinants of allowing Marxist responses not to stop at economic analyses but to release, rather than inhibiting, new revolutionary subjects and directions. Critical for the present moment is to take up Marx's humanism and dialectic as crucial dimensions of his philosophy of revolution in permanence. This encompasses not alone the famous March 1850 Address to the Communist League, but also the full trajectory of Marx's revolutionary life and thought from the 1844 Economic-Philosophic Manuscripts through Capital to the new moments of Marx's last decade as expressed in his writings on Russia and his Ethnological Notebooks. We trace Marx's theoretical/philosophical concept of permanent revolution in a number of his writings, to confront how various post-Marx Marxists addressed or ignored this dimension of Marx's thought, and explore whether this concept can be seen as central to Marx's body of thought, and can assist in the dual task of needed revolutionary transformation - the destruction of the old (negation) and the construction of the new (the negation of the negation).
\end{abstract}

Keywords: Karl Marx, revolution, permanent revolution, Leon Trotsky, Mao Zedong, Raya Dunayevskaya, Marxist humanism, women's liberation

\section{Introduction}

If Marx is to mean anything for today, then it must be in helping us confront the problem of how to make revolutionary new beginnings at a time when counterrevolution is ascendant. Short-term economic statistics such as falling unemployment or rising GDP growth cannot cover up the serious crisis in which world capitalism languishes, not only economically but in wars, political reaction, and the bankruptcy of thought. From staggering economic inequality to the flight of climate/economic refugees from Puerto Rico, from genocide in Syria and Myanmar to the rise of the far-right to government in Austria, from President Donald Trump's virtual endorsement of the murderous racist demonstration in Virginia to the sycophantic chorus of intellectuals and pundits rationalising every mendacious utterance of Trump, the world situation screams of capitalism's inability to reverse deepening crises and avert its selfdestruction, whether through climate chaos or nuclear war. This is little consolation to those seeking liberation, since the far-right is working overtime to divert and exploit mass discontent.

At the same time, interest in Karl Marx has resurged because of the deep economic crisis, and even more so because of the revolutions that became 2011's Arab 
Spring, leading to a worldwide wave that returned revolution to centre stage. The complications that quickly ensued underscored the unfinished nature of the revolutions and movements, and the need for what Marx called revolution in permanence. The Arab Spring, however unfinished, helped inspire revolts, from the town square occupations by indignados in Spain to the Occupy Wall Street movement that spread across the US - and, just as importantly, a resurgence of the idea of revolution. In each case demands for political freedom against the monopoly of power by a small elite were fused with a quest for fundamental changes in economic relations, in a way that brought to the fore the questions at the heart of Marx's revolutionary life.

Marx's concept of permanent revolution elucidated the need for freedom struggles not to stop at the first stage but to continue on, until human relations were fundamentally transformed, including relations in production that define the economic structure. Today, this can only be meaningfully interpreted as encompassing many facets of human relations, not limited to the economy in a narrow sense.

Though the concept of permanent revolution is most often referred to in terms of the theory that Leon Trotsky developed out of the 1905 Russian Revolution, Marx had in fact referred to the concept several times. Even when Marx's writing on permanent revolution is referred to, most often it is limited to the important March 1850 Address to the Communist League by Marx and Engels. Interpretation of that 1850 Address has often been reduced to a question of strategy for continuing the 1848-49 revolutions, or criticising the authors for believing that "a new revolution is impending" (Marx and Engels 1978/1850, 278).

Here we wish to consider permanent revolution in Marx not alone as strategy or "action", as important as that is, but as key to his development of a philosophy of revolution. In our view he planted the seeds for such a concept in 1843-44. Marx adopted the term "permanent revolution" - which had probably appeared in the Great French Revolution (Draper 1978, 203; 591-595) -as early as 1843. It was only in the following year that he worked out the foundations of his philosophy and economic theory in his 1844 Economic-Philosophic Manuscripts. There he critiqued and recreated the Hegelian dialectic, developing its "negation of the negation" as a "consistent naturalism or humanism" (Marx 1967a/1844, 317; 321; 325) that went beyond communism (Marx 1967c/1844). Out of this emerged the inseparability of humanism and dialectics with his concept of permanent revolution. Precisely this unity would be found in Marx's writing and practice around the 1848-49 Revolutions, in his magnum opus Capital, in his Critique of the Gotha Program's view of labour after the revolution, and in his searching for new revolutionary beginnings globally, be it in analyses of the Russian peasant commune or in notes on non-capitalist societies in his Ethnological Notebooks.

We argue that this fusion of humanism and dialectics - reflected in Marx's lifework over four decades - provides the ground for interpreting Marx's Marxism as a philosophy of revolution in permanence that has crucial significance for giving action its direction in our day.

\section{Permanent Revolution in Marx}

\subsection{Origin of the Concept as Concretisation of the Hegelian Negation of the Negation: Human Emancipation vs. Political Emancipation}

Marx's 1843 essay “On the Jewish Question”, while favouring the emancipation of the Jews, argued that a political change was insufficient. Calling attention to "the rela- 
tion between political emancipation and human emancipation" (Marx 1967b/1844, 221), he contrasted political revolution with permanent revolution:

Political emancipation is indeed a great step forward. It is not, to be sure, the final form of universal human emancipation, but it is the final form within the prevailing order of things. [...] In moments of special concern for itself political life seeks to repress its presupposition, civil society and its elements, and to constitute itself the actual, harmonious species-life of man. But it can do this only in violent contradiction with its own conditions of existence by declaring the revolution to be permanent. [...] The political revolution dissolves civil life into its constituent elements without revolutionizing these elements themselves and subjecting them to criticism. (Marx 1967b/1844, 227-228; 240)

Therefore, from the beginning, Marx's concept of permanent revolution involved a vision of totally new human relations. The implicit reference to the barriers met by the French Revolution suggests that the concept was rooted in taking off from the past high point of revolution, yet with cognisance of the counterrevolution within the revolution. The argument suggests that permanent revolution represents a second negation, negating political revolution as the first negation of oppression, in order to achieve full human emancipation.

Marx developed that viewpoint on a profound philosophical level in his 1844 Economic-Philosophic Manuscripts, though not using the word "permanent". There he worked out his break with classical political economy, with vulgar communism, and with the dehumanisation of the dialectic by Hegel. This triple break was at the same time the foundation of a new kind of humanism, dialectical and, as Antonio Gramsci put it, "absolute 'historicism,' [...] an absolute humanism of history" $(1971,465)$. The triple break shifts focus from things to the human being as revolutionary subject: from private property to labour as the heart of the contradiction of capitalism, from labour as source of value to the labourer as subject, from the alienation of the product of labour to the alienation of the activity of labour, and from history as the movement of consciousness to the self-production of humanity through its own self-activity, with labour as self-development.

Marx arrived at that triple break and new humanism in responding to the rise of proletarian revolt in the 1840s, while at the same time not discarding the Hegelian dialectic and its negation of the negation, but rather recreating it on the revolt's basis as a "consistent naturalism or humanism [which] is distinguished from both idealism and materialism as well, and at the same time is the unifying truth of both" (Marx 1967a/1844, 325). A key way that Marx directly expresses the second negation is as the need to go beyond communism, to assure no halt at the first negation - the toppling of the exploitative society - but to develop the transcendence of alienation through the appropriation of the wealth of human capacities and needs, or "the actual appropriation of his objective nature by the destruction of the alienated character of the objective world" so that there "emerges positive humanism, humanism emerging positively from itself" (Ibid., 331). He held absolute negativity to be Hegel's "moving and creating principle", which the old materialism did not match. Thus Marx continued, even in his mature work Capital, to return to the Hegelian dialectic as "the source of all dialectics" (Marx 1990/1867, 744). In concretising that dialectic of negativity as alienation and its transcendence through class struggles and the relationship between the sexes, Marx in 1844 created a philosophy of revolution in permanence. 


\subsection{Summing up the 1848 Revolutions: Declaring the Revolution Permanent}

After the experience of the 1848-49 revolutions, Marx and Engels concretised that philosophy as theoretical preparation for the next revolution in their March $1850 \mathrm{Ad}$ dress to the Communist League. It is best known for insisting on the highest point reached by revolution: a proletarian movement independent of other classes, and the need not to stop with the first phase of revolution but constantly to radicalise it, pushing for a second revolution. This entailed the need for world revolution for the German revolution to succeed.

The Address points to a quest for bringing out new revolutionary forces, beginning with the rural proletariat - and it was soon followed by Engels's The Peasant War in Germany, one of the most important theoretical writings in Marx's 1850 journal, the Neue Rheinische Zeitung Revue. Within a few years Marx would refer to the need for "supporting the proletarian revolution with a sort of second edition of the peasant war" (Marx and Engels 1983, 41). Later still he would turn to the question of the Russian peasant commune.

What cannot be separated from the refusal to stop at the first phase of revolution is the bold vision of a new classless society laid out in the Address:

While the democratic petty bourgeois wish to bring the revolution to a conclusion as quickly as possible [...] it is our interest and our task to make the revolution permanent, until all more or less possessing classes have been forced out of their position of dominance, the proletariat has conquered state power, and the association of proletarians, not only in one country but in all the dominant countries of the world, has advanced so far that competition among the proletarians in these countries has ceased and that at least the decisive productive forces are concentrated in the hands of the proletarians. For us the issue cannot be the alteration of private property but only its annihilation, not the smoothing over of class antagonisms but the abolition of classes, not the improvement of the existing society but the foundation of a new one (Marx and Engels 1978/1850, 281).

Restating "the conception of the movement as laid down in the circulars of the congresses and of the Central Authority of 1847 as well as in the Communist Manifesto" (Ibid., 277), this vision was rooted in Marx's conception of philosophy and revolution. Just as he had projected in 1844 both the overthrow of the old and the need to change human relationships totally, this Address projected the interrelation between international extension of revolution and the deepening of the concrete revolution.

\subsection{Mature Economic Theory and Forces of Human Emancipation}

Without using the term "permanent revolution", Marx developed a new aspect of the concept in his economic theory of the 1850s, relating resistance by non-capitalist countries suffering capitalism's exploitation to his concept of an "era of social revolution" (Marx 1987/1859, 263; Marx 1990/1867, 164 n. 27). A new revolutionary force, the Black liberation struggle in the US Civil War, became part of Marx's theory as he restructured Capital in response to the Civil War and the ensuing movement for the eight-hour day. It was then that he added a chapter on the struggles around the length of the working day (Dunayevskaya 2000/1958, 81-91). In so doing, he broke with the concept of theory as a debate with theoreticians, practicing theory instead as a history of class struggles and production relations - and he singled out the underlying philosophy created by the workers: 
In place of the pompous catalogue of the "inalienable rights of man" there steps the modest Magna Carta of the legally limited working day, which at last makes clear "when the time which the worker sells is ended, and when his own begins." (Marx 1990/1867, 416)

The final edition of Volume I of Capital produced under Marx's supervision, the 187275 French edition, similarly reflected the impact of the 1871 Paris Commune (Dunayevskaya 2000/1958, 92-102). From that revolution emerged both the discovery of "the political form at last discovered under which to work out the economical emancipation of labor" (Marx 1986/1871, 334) and a new force of revolution: women.

To reduce Capital to the dialectic of capitalism's development, to miss its humanism, as if the Subject is capital itself and not the human being confronting capital, is to violate the unity of dialectics and humanism that is at the heart of Marx's theory. Capital as a whole refuses to separate economic theory from the need for not simply political emancipation or narrowly economic change but universal human emancipation. This is seen not only in the projection of a future of freely associated labour (Marx 1990/1867, 171; 173), but in the very categories that conceptualise the duality of labour under capitalism throughout the four volumes: abstract labour vs. concrete labour, constant capital vs. variable capital, the dialectical inversion in which object, dead labour (capital, especially in the form of machines), dominates the subject, living labour (the worker). It culminates in the explicit identification of "negation of the negation" with proletarian revolution in the chapter on "The Historical Tendency of Capitalist Accumulation" (Marx 1990/1867, 927-930).

\subsection{Permanent Revolution as the Multilinearity of World Revolution}

That historical tendency was a universal - but only for countries where the capitalist mode of production already predominated, as Marx took pains to point out in his final years, when he fully developed the multi-linear nature of his concept of permanent revolution. Another path to revolution may be possible for non-capitalist societies (Marx 1989b/1877, 196-201). Marx honed in on Russia and the revolutionary potential of its peasant communes in his critique of Nikolai Mikhailovsky and the drafts of his letter to Vera Zasulich, declaring in the preface to the 1882 Russian edition of the Communist Manifesto:

If the Russian Revolution becomes the signal for a proletarian revolution in the West, so that the two complement each other, the present Russian common ownership of land may serve as the starting point for a communist development (Marx and Engels 1989/1882, 426)

In the last decade of Marx's life, his search for new paths to revolution, including in technologically "underdeveloped" societies, turned to anthropological and historical studies of societies in non-capitalist lands and pre-capitalist times - this from the author of Capital! To Raya Dunayevskaya, Marx's late Ethnological Notebooks disclosed "new moments" on topics ranging from the Man/Woman relationship to societies where other modes of production prevailed, and from ancient communal social forms to revolutionary organisation (Dunayevskaya 1991/1982, 175-197). The new moments were seen not as a break but as a development in continuity with his 1844 humanism and Capital. The discoveries of his last decade, she wrote, extended his concept of permanent revolution because they made clear how deep must be the uprooting of class society and how broad the view of the forces of revolution. It led 
Marx to projecting nothing short of the possibility of a revolution occurring in a backward land like Russia ahead of one in the technologically advanced West.

A related aspect of permanent revolution, the movement of the negation of the negation, is seen in another important late work of Marx, the Critique of the Gotha Programme. What is key for this discussion is Marx's attack on the Gotha Programme's inadequate and incoherent projection of "a fair distribution of the proceeds of labour". He does not satisfy himself with proving the meaninglessness of "fair distribution" but outlines how any initial stage of post-revolutionary society is incomplete and still bears the birthmarks of capitalist society. What is necessary is to project the vision of full emancipation, with abolition of the division between mental and manual labour and of the subordination of the individual to the division of labour, and with labour itself becoming not only means to life but the kind of self-activity that is life's prime need (Marx 1989a/1875, 83-88). The movement of second negation is spelled out not only as moving from the first phase of revolution to the next, not only to a second revolution, but moving from the first post-revolutionary order to a new one that develops on its own basis, a positive humanism beginning from itself, as he had put it in 1844. This emerges from a critique of an organisational program, suggesting that he sees the projection of this vision as not only a distant goal but a moving force even before the revolution.

\section{Marxist Interpretations of Permanent Revolution}

Unfortunately, interpretations of Marx's writings on permanent revolution almost always reduce it to the question of moving quickly from the first, bourgeois-democratic phase of revolution to a second, proletarian-socialist one. This is indeed important, but the whole concept is narrowed when this one point is separated out as a strategy devoid of philosophy.

The best-known theory of permanent revolution is not Marx's but Leon Trotsky's. The name was actually bestowed by a Menshevik critic as a form of mockery, reflecting the suspicion with which much of Second International Marxism viewed Marx's supposedly "Blanquist", too-radical 1850 Address. Trotsky, however, was happy to accept the designation. His theory was compatible with Marx's in the sense that it called for continuing the revolution to a second stage. He rejected the Menshevik view that Russia's economic development could not sustain more than a bourgeoisdemocratic revolution. Trotsky insisted that, while a bourgeois-democratic revolution was needed, it would have to be brought about by the working class and could pass over immediately into socialist revolution in an "unbroken chain" (Trotsky 2010/1930, 145). He rejected the Menshevik position that all countries must follow a single path of development; Russia need not recapitulate England's trajectory. Its revolution could take advantage of the advanced development of class struggles in Western Europe. Thus his theory was rooted in world revolution, with combined and uneven development. However, he downplayed the peasantry as potential subject of revolution, though it was the majority of the Russian population, and even more dominant in countries like China. He disparaged its capability for an independent political role (Trotsky 1977a/1934, 1262). Even with the proletariat, he was fixated on its "immaturity" (Trotsky 1977b/1938, 148). Thus, Trotsky's theory was fatally removed both from Marx's and from contemporary reality.

Mao Zedong, while building on Stalinism, adopted the phrase "uninterrupted revolution" (Marx's "Revolution in Permanenz" can be translated as "uninterrupted," "continuous," or "permanent revolution"). This, however, had little to do with Marx's concept. Mao explicitly rejected the Hegelian concept of the negation of the negation 
and, in the first instance, used the phrase to anoint the forced labour of the catastrophic Great Leap Forward, and later reduced Marx's concept of proletarian revolution to "cultural revolution" (Lin 1965). Mao's perversion of the concept is clear enough in the constitution adopted by the Chinese Communist Party in 1969:

Socialist society covers a considerably long historical period. Throughout this historical period, there are classes, class contradictions and class struggle. [...] These contradictions can be resolved only by depending on the Marxist theory of continued revolution and on practice under its guidance. Such is China's Great Proletarian Cultural Revolution, a great political revolution carried out under the conditions of socialism by the proletariat against the bourgeoisie and all other exploiting classes.

The whole Party must hold high the great red banner of Marxism-LeninismMao Tsetung Thought and lead the hundreds of millions of the people of all the nationalities of our country in carrying on the three great revolutionary movements of class struggle, the struggle for production and scientific experiment (Communist Party of China 1969).

In contrast to these interpretations of Marx's concept, the Marxist-Humanist revolutionary Raya Dunayevskaya analysed Marx's Ethnological Notebooks and other writings of his last decade as "new moments of the revolutionary philosophic-historic concepts" of Marx (Dunayevskaya 1991/1982, 180-191). She saw them as a new concretisation of Marx's concept of revolution in permanence, and that in turn as a recreation of Hegel's negation of the negation. This concept meant that revolution must continue after the conquest of power to a profound transformation of human relations:

The aim was to show how total the uprooting of the old must be, be it in work, or culture, or leisure, or self. And with it, how total freedom must be, which was the meaning of Marx's "revolution in permanence," that is, to continue after the overthrow of the old, at which point the task becomes most difficult, as it involves nothing short of such full self-development that the division between mental and manual is finally abolished (Dunayevskaya 2018/1986).

From this work arose her views of Marx as philosopher of revolution in permanence and, in contrast, of what she called post-Marx Marxism as a truncated Marxism that failed to draw on the totality of Marx's philosophy. This dual view of Marx and Marxism meant to her a philosophy that could address the problem of unfinished revolutions of the 20th century - a problem we still face today - including transformation into opposite as in the case of the Russian Revolution turning into state-capitalist totalitarianism, as well as revolutions that stop short, as with Egypt's 2011 revolution. It meant also that revolutionary organisation must be grounded in revolution in permanence, not only as strategy and politics but as philosophy.

Dunayevskaya extended the concept to address women's liberation, seeing it as a dimension of Marx's concept of permanent revolution as early as his 1844 Economic-Philosophic Manuscripts, where he brought up the Man/Woman relationship as measure of the inadequacy of what he called vulgar communism, but also of how deep and total the social uprooting needs to be. Then the Communist Manifesto called for the abolition of the family and "class culture" (Marx and Engels 1976, 501) as well as of private property and the state. She held that his vision of the "absolute 
movement of becoming" (Marx 1973/1858, 488) was a translation of "revolution in permanence" (Dunayevskaya 1996/1985, 192; 203). It also meant giving space in a developing postrevolutionary society for what would replace the family as we know it:

We are so backward on the whole question that we will have to go through a lot of stages of actual experimentation, with people having the right to choose. [...] That is why I emphasize that the expression "revolution in permanence" as Marx used it [...] was not just a political expression, the overthrow of the old regime. That is only the first stage. Now that you've gotten rid of what is, what are you going to do to create the new?

Marx's Critique of the Gotha Program is the finest critique in the sense of seeing that the revolution in permanence has to continue after the overthrow. Yes, there's the idea that there's a transition period, and the state will wither away but in our age we know that we've seen an awful lot not of withering away but the state getting totally totalitarian. So the point is the recognition of what Marx meant by revolution in permanence, that it has to continue afterwards, that it encompasses the criticism that's necessary, the self-criticism that's necessary, and the fact that you have to be very conscious that until we end the division between mental and manual labor [...] we will not really have a new man, a new woman, a new child, a new society. [...] You must never forget that the revolution in permanence refers to you too, not just to the enemy, and that it has to be continuous after the day of the revolution and the conquest of power, as much as the day before (Dunayevskaya 1996/1985, 181-182).

We argue that this conversion of Marx's concept of permanent revolution into the fullness of a philosophy reveals precisely the Marx that is needed for our day.

\section{The Significance of Marx's Revolution in Permanence for Our Day}

We need to grapple with Marx not only as economist, politician, organiser, historian, but most crucially as philosopher of permanent revolution. For what is so needed for our day is the creation of an overarching vision, a pole of attraction that a revolutionary philosophy can be. That revolutionary philosophy must of necessity be the foundation for a dialectic of organisation.

How can Marx's ideas help us with the problem of how to make new revolutionary beginnings in a time when the counterrevolution is ascendant, without losing sight of the need to prepare for the equally crucial question of what happens after the revolution? Capitalism has taken various forms as it developed, with the latest apparently suicidal stage - as seen most glaringly in the steady march toward climate chaos shaped by its endemic crisis since the mid-1970s generated by its falling rate of profit. Throughout these stages, the humanism and dialectic of Capital remain prime determinants of allowing Marxist responses not to stop at economic analyses but to release, rather than inhibiting, new revolutionary subjects and directions. Critical for the present moment is to take up Marx's humanism and dialectic as essential dimensions of his philosophy of revolution in permanence.

This decade has seen no shortage of discontent, resistance, revolt, even revolution. What is needed is not another vanguard party, not another mind-numbing lecture to social movements of the need for a political agenda, strategy, and tactics, nor a fatalistic belief that capitalism will collapse all on its own, or that gathering revolt will spontaneously generate the new society, making theory superfluous. We must reck- 
on with the character of this moment, when not only centrist bourgeois politics but fascism on the right and apologetics for Bashar al-Assad's genocide on the "left" are pulling to disorient the masses of people dissatisfied with the ongoing social disintegration. What must be stressed today is the role of a unifying philosophy that points to the need for revolution in permanence, and its potential to act as a polarising force for universal human emancipation, to make real the negation of the negation as the dual rhythm of revolutionary transformation: the destruction of the old and the construction of the new.

\section{References}

Communist Party of China. 1969. Constitution of the Communist Party of China. Accessed January 30, 2018.

https://www.marxists.org/subject/china/documents/cpc/ninth congress2.htm

Draper, Hal. 1978. Karl Marx's Theory of Revolution: Volume II. New York: Monthly Review Press.

Dunayevskaya, Raya. 2018/1986. Letter to Adrienne Rich on Women's Liberation, Gay Liberation, and the Dialectic. In Marx's Philosophy of Revolution in Permanence for Our Day: Selected Writings by Raya Dunayevskaya, edited by Franklin Dmitryev. Leiden: Brill.

Dunayevskaya, Raya. 2000/1958. Marxism and Freedom, from 1776 until Today. Amherst, MA: Humanity Books.

Dunayevskaya, Raya. 1996/1985. Women's Liberation and the Dialectics of Revolution: Reaching for the Future. Detroit, MI: Wayne State University Press.

Dunayevskaya, Raya. 1991/1982. Rosa Luxemburg, Women's Liberation, and Marx's Philosophy of Revolution. Urbana, IL: University of Illinois Press.

Gramsci, Antonio. 1971. Selections from the Prison Notebooks. New York: International Publishers.

Lin Biao. 1965. Long Live the Victory of People's War! Accessed January 30, 2018. https://www.marxists.org/reference/archive/lin-biao/1965/09/peoples war/ch07.htm

Marx, Karl. 1990/1867. Capital: A Critique of Political Economy: Volume I. London: Penguin.

Marx, Karl. 1989a/1875. Critique of the Gotha Programme. In Marx-Engels-Collected Works (MECW), Volume 24, 75-99. New York: International Publishers.

Marx, Karl. 1989b/1877. Letter to Otechestvenniye Zapiski. In Marx-Engels-Collected Works (MECW), Volume 24, 196-201. New York: International Publishers.

Marx, Karl. 1987/1859. A Contribution to the Critique of Political Economy: Part One. In Marx-Engels-Collected Works (MECW), Volume 29, 257-417. New York: International Publishers.

Marx, Karl. 1986/1871. The Civil War in France. In Karl Marx Frederick Engels Collected Works: Volume 22, 307-359. New York: International Publishers.

Marx, Karl. 1973/1858. Grundrisse. New York: Vintage Books.

Marx, Karl. 1967a/1844. Critique of Hegel's Dialectic and Philosophy in General. In Writings of the Young Marx on Philosophy and Society, edited and translated by Loyd D. Easton and Kurt H. Guddat, 314-337. Garden City, NY: Anchor Books.

Marx, Karl. 1967b/1844. On the Jewish Question. In Writings of the Young Marx on Philosophy and Society, edited and translated by Loyd D. Easton and Kurt H. Guddat, 216-248. Garden City, NY: Anchor Books.

Marx, Karl. 1967c/1844. Private Property and Communism. In Writings of the Young Marx on Philosophy and Society, edited and translated by Loyd D. Easton and Kurt H. Guddat, 301-314. Garden City, NY: Anchor Books.

Marx, Karl and Frederick Engels. 1989/1882. Preface to the Second Russian Edition of the Manifesto of the Communist Party. In Marx-Engels-Collected Works (MECW), Volume 24, 425-426. New York: International Publishers.

Marx, Karl and Frederick Engels. 1983. Marx-Engels-Collected Works (MECW), Volume 40. New York: International Publishers. 
Marx, Karl and Frederick Engels. 1978/1850. Address of the Central Authority to the League. In Marx-Engels-Collected Works (MECW), 277-287. New York: International Publishers.

Marx, Karl and Frederick Engels. 1976/1848. Manifesto of the Communist Party. In MarxEngels-Collected Works (MECW), Volume 6, 477-519. New York: International Publishers.

Trotsky, Leon. 2010/1930. The Permanent Revolution \& Results and Prospects. Seattle: Red Letter Press.

Trotsky, Leon. 1977a/1934. The History of the Russian Revolution. London: Pluto Press.

Trotsky, Leon. 1977b/1938. The Transitional Program for Socialist Revolution. New York: Pathfinder Press.

\section{About the Authors}

Eugene Gogol

Eugene Gogol is an independent researcher; author of Utopia and the Dialectic in Latin American Liberation (Brill, Haymarket), Toward a Dialectic of Philosophy and Organization (Brill, Haymarket), Mariátegui y Marx (Universidad Nacional Autónomo de México).

\section{Franklin Dmitryev}

Franklin Dmitryev: Editor, Marx's Philosophy of Revolution in Permanence for Our Day: Selected Writings by Raya Dunayevskaya (Brill, forthcoming); author of "Climate Change and Creative Revolt" (Countervortex.org, August 2016), "Occupy: Democracy, Revolution and Philosophy" (News \& Letters, September-October 2015), "Greece: Postmodernism in Power" (News \& Letters, March-April 2015). 